\title{
Streamflow variation due to glacier melting and climate change in upstream Heihe River Basin, Northwest China
}

\author{
Feng $\mathrm{Wu}^{\mathrm{a}}$, Jinyan Zhan ${ }^{\mathrm{a}, *}$, Zhan Wang ${ }^{\mathrm{b}}$, Qian Zhang ${ }^{\mathrm{b}}$ \\ ${ }^{a}$ State Key Laboratory of Water Environment Simulation, School of Environment, Beijing Normal University, Beijing 100875, China \\ ${ }^{\mathrm{b}}$ Center for Chinese Agricultural Policy, Institute of Geographic Sciences and Natural Resources Research, Chinese Academy of Sciences, Beijing 100101, China
}

\section{A R T I C L E I N F O}

\section{Article history:}

Received 9 March 2014

Received in revised form 24 July 2014

Accepted 9 August 2014

Available online 18 September 2014

\section{Keywords:}

Streamflow simulation

Glacier melting

Snowmelt

Water balance

Hydrological model

\begin{abstract}
A B S T R A C T
Streamflow simulation is often challenging in mountainous watersheds because of incomplete hydrological models, irregular topography, immeasurable snowpack or glacier, and low data resolution. In this study, a semi-distributed conceptual hydrological model (SWAT-Soil Water Assessment Tool) coupled with a glacier melting algorithm was applied to investigate the sensitivity of streamflow to climatic and glacial changes in the upstream Heihe River Basin. The glacier mass balance was calculated at daily time-step using a distributed temperature-index melting and accumulation algorithm embedded in the SWAT model. Specifically, the model was calibrated and validated using daily streamflow data measured at Yingluoxia Hydrological Station and decadal ice volume changes derived from survey maps and remote sensing images between 1960 and 2010. This study highlights the effects of glacier melting on streamflow and their future changes in the mountainous watersheds. We simulate the contribution of glacier melting to streamflow change under different scenarios of climate changes in terms of temperature and precipitation dynamics. The rising temperature positively contributed to streamflow due to the increase of snowmelt and glacier melting. The rising precipitation directly contributes to streamflow and it contributed more to streamflow than the rising temperature. The results show that glacial meltwater has contributed about 3.25 billion $\mathrm{m}^{3}$ to streamflow during 1960-2010. However, the depth of runoff within the watershed increased by about $2.3 \mathrm{~mm}$ due to the release of water from glacial storage to supply the intensified evapotranspiration and infiltration. The simulation results indicate that the glacier made about $8.9 \%$ contribution to streamflow in 2010. The research approach used in this study is feasible to estimate the glacial contribution to streamflow in other similar mountainous watersheds elsewhere.
\end{abstract}

(c) 2014 Elsevier Ltd. All rights reserved.

\section{Introduction}

The hydrological processes of mountainous watersheds are altered by climate change, but the influencing extent is unclear yet (Akhtar et al., 2008; Immerzeel et al., 2014). Runoff from snow and glacier melting is the main water resource in the mountainous watersheds, contributing to about $30-50 \%$ of the total water discharge in some arid regions (Viviroli and Weingartner, 2004; Yin et al., 2014). Monitoring of glacier variation, analyzing their response to climate change, and estimating and predicting of streamflow variation due to glacier variation are of highly scientific and practical significance. Water resources in glacier-fed watersheds will diminish due to climate change and significantly affect the social-economic development in the entire basin (Hagg et al.,

\footnotetext{
* Corresponding author. Tel.: +86 13521071561; fax: +861059893226.

E-mail addresses: wuf.dls@gmail.com (F. Wu), zhanjy@bnu.edu.cn (J. Zhan), lizwang128@gmail.com (Z. Wang), zhangq.ccap@igsnrr.ac.cn (Q. Zhang).
}

2007; Luo et al., 2013). Large-scale simulation of mountainous hydrology is the most feasible of estimating the impacts of potential climate change and glacier melting on the water resource (Fontaine et al., 2002). At mountainous watersheds, melting and runoff generation process, water yield and its spatiotemporal distribution, and contribution of glacier to streamflow are the key issues to be addressed (Luo et al., 2013), and simulation of the long-term effects of the glacier melting is crucially important. However, the streamflow simulation research is often challenging for the complex hydrological processes and poor climate data resolution in the mountainous watersheds (Hock, 2003; Howells et al., 2013).

Climate change will substantially alter the streamflow characteristics and lead to drastic glacier melting or complete wastage of glacier during the next decades (Huss et al., 2008b; Thorsteinsson et al., 2013). On one hand, changes in the precipitation amount will affect the runoff volume and particularly the maximum snow accumulation, which usually occurs between the 
late winter and the early melt season. On the other hand, the temperature changes mostly influence the timing of runoff (Barnett et al., 2005). Model simulation is an effective tool for analyzing the contributions of climate change and glacier melting to runoff variation (Luo et al., 2013). Specially, the long-term runoff was forecasted by the climate model, but the physical processes, such as snow or glacier melting, have been rarely studied (Beniston, 2012). The hydrologic component of Soil and Water Assessment Tool (SWAT) has been tested widely in some watersheds where streamflow is mainly generated from rainfall events (Arnold et al., 1999; Castillo et al., 2014; Nie et al., 2011; Wang and Melesse, 2005; Zang et al., 2012). Some studies were conducted to test and improve the SWAT snowmelt algorithm for streamflow simulation related to the impact of climate variations in mountainous watersheds (Debele et al., 2010; Fontaine et al., 2002; Liew and Garbrecht, 2003; Zeng et al., 2012). However, long-term effects of glacier melting and snow melting on hydrological process in mountainous watersheds is underexplored, and to date a constructive and reliable module on glacier melting in SWAT is also under development and needs further parameterization.

In this paper, we explored the glacier variation and its effects on streamflow, and investigated the change in the amount of glacial water in the context of global warming given its crucial role as the main water resource in Northwest China (Liu et al., 1999). Previous studies concluded that the total glacier melting area is up to $138.9 \mathrm{~km}^{2}$ in the upstream Heihe River Basin in Northwest China during the summer time from 1960 to 2010 (Wang et al., 2009), and recent warming trends in the Heihe River Basin are accompanied by increasing trends of streamflow (Akiyama et al., 2007; Li et al., 2009). After the initial shift from a positive or neutral mass balance to a negative one, the amount of melt water will increase due to the earlier disappearance of high-albedo snow, the exposure of lower-albedo snowpack and/or ice and the increased energy inputs (Singh and Kumar, 1997). In some sense, it is not only a challenge but also a chance to build a model based on climate change and the dynamics of glacier melting to investigate the sensitivity of streamflow to climatic and glacial changes in the upstream Heihe River Basin.

\section{Study area}

The Heihe River Basin is located in a typical arid region of Northwest China that suffers from serious water scarcity. The Heihe River Basin is divided into the upper, middle and lower reaches, which differ significantly in natural and socioeconomic characteristics. For example, the average annual precipitation is 200$500 \mathrm{~mm}$, less than $200 \mathrm{~mm}$, and less than $50 \mathrm{~mm}$ in the three reaches respectively, while the annual evaporation ranges from $700 \mathrm{~mm}$ in the upper reach to more than $3000 \mathrm{~mm}$ in the lower reach (Feng et al., 2001; Zang et al., 2013). The geography varied greatly in Heihe River Basin, with the average altitude over $1200 \mathrm{~m}$. The ecosystem patterns range from alpine ecosystems on the south Qilian Mountain in the upstream, to the oases at the Hexi Corridor in midstream basin, and to the deserts in the north downstream basin (Li et al., 2009; Wang et al., 2009).

In this study, the upstream Heihe River Basin is selected as the study area, where the elevation ranges from $2000 \mathrm{~m}$ at the lower point to about $5500 \mathrm{~m}$ at the headwaters (Fig. 1). The south Qilian Mountains with remarkably vertical zonality is the water source area, where the ecosystem patterns ranging from low to high altitude include dry shrubbery grassland, forest grassland, sub-alpine shrubbery meadow, alpine cold-and-desert meadow, and alpine permafrost-snow-ice (Yin et al., 2014). The annual mean precipitation increases from about $200 \mathrm{~mm}$ in the low-mountain/hill zone to about $500 \mathrm{~mm}$ in the high-mountain zone. The main soil types in the watershed are alpine meadow soil, alpine steppe soil, frigid desert soil, gray cinnamonic soil and gray-brown desert soil. The glacier melting mainly occurs in the east part of the upstream area, and the glaciers in the middle and west parts of Qilian Mountains had stabilized due to continuous temperature reduction and concurrent precipitation increase since the 1960s (Liu et al., 1999).

\section{Methods}

SWAT is a semi-distributed hydrological model based on geography and natural hydrologic processes at watershed scale. SWAT subdivides an entire watershed into sub-watersheds connected with a river network and into smaller units called Hydrological Response Units (HRUs). Each HRU represents a combination of land use, soil and slope, and all HRUs are assumed to be non-spatially distributed with no interaction or dependency (Neitsch et al., 2005). SWAT has been successfully applied worldwide to solve many environmental issues in water quality and quantity studies (Pradhanang et al., 2011; Varanou et al., 2002). Major model components of SWAT include weather, hydrology, soil temperature and properties, plant nutrients and growth, pesticides, bacteria and land management (Neitsch et al., 2005). The meteorological variables in SWAT include precipitation, temperature, wind speed, solar radiation, and relative humidity in daily or sub-daily time steps. The hydrological routine of SWAT actually and potentially consists of discharge, snow melting, and evapotranspiration. In this study, the processes related to glacier melting in mountainous watersheds were addressed, and the snowmelt runoff is the source of water resource replenishment in the spring. Therefore, we introduced the snowmelt process and a glacier melting module to the classic SWAT model, and formulated the relationship between glacier melting and temperature. Data used in this study are presented in Table 1.

\subsection{Simulation of glacier mass balance}

Research on the long-term streamflow simulation in glacier-fed watersheds must take into account the changes in ice volume. Glacier runoff was calculated as follows. First, we assumed typical mass balance gradients for alpine glaciers to be $-0.009 \mathrm{a}^{-1}$ for the ablation and $-0.005 \mathrm{a}^{-1}$ for the accumulation area (Huss et al., 2008a), and we then derived the mass balance distribution using a Digital Elevation Model (DEM). The area-averaged mass balance of the glacier surface was set to be 0 . Second, a balanced ice flux was defined as the sum-up of the ice volume gain and loss during a year at intervals of $300 \mathrm{~m}$. Third, an ice flow law in an integrated form (Glen, 1955) was solved for the ice thickness $h$ on the central flow-line.

$h=\sqrt[5]{\frac{q}{\frac{2}{5} h A\left(S_{f} \rho g \sin \bar{a}\right)}}$

where $q\left(\mathrm{~m}^{2} \mathrm{~s}^{-1}\right)$ is the ice flux normalized with glacier width, $g$ is the acceleration of gravity, $A$ is the rate factor of the ice flow law (Glen, 1955), $S_{f}$ is a factor accounting for the valley shape (Nye, 1965), $\rho$ is the ice density, and $\bar{a}$ is the slope of the glacier surface. $A$ is calibrated to optimize agreement with the radio-echo sounding profiles. We set $A=6 \times 10^{-15} \mathrm{~s}^{-1} \mathrm{kPa}^{-3}$ which is consistent with a previous study (Huss et al., 2008b). $S_{f}=0.6$ is cited from a literature (Nye, 1965), and $\bar{a}$ is equal to the mean slope along the flow-line. Finally, the spatially distributed values of $h$ were connected by accounting for the local surface slope at every grid cell and by assuming $h \sim(\sin \bar{a})^{3 / 5}$. This proportionality presents the redistribution of ice along the cross-flow section. The selected proportionality factor guarantees that the previous total ice volume is unchanged. Surface melt rate $M_{g l a}$ is computed as follows: 


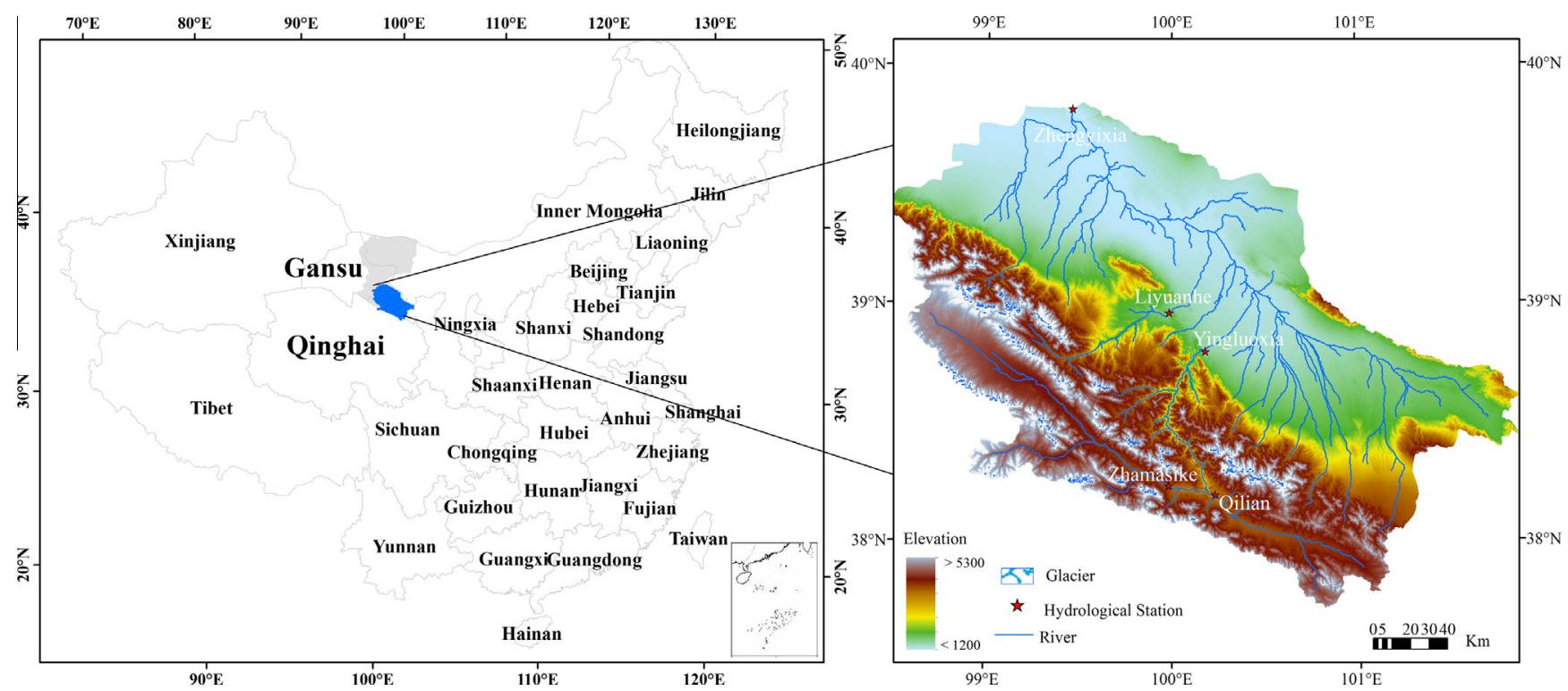

Fig. 1. Location and hydrological distribution of mountain glaciers in the Heihe River Basin.

Table 1

Data used and sources.

\begin{tabular}{|c|c|c|c|}
\hline Data type & Data source & Scale & Description \\
\hline DEM & $\begin{array}{l}\text { Shuttle Radar Topography Mission } \\
\text { (SRTM) }\end{array}$ & $90 \mathrm{~m}$ & Elevation \\
\hline Land use & $\begin{array}{l}\text { Data Center of Chinese academy of } \\
\text { Science }\end{array}$ & $1: 100,000$ & The land use classification system contains 25 categories \\
\hline Soil & $\begin{array}{l}\text { Regional Database (http:// } \\
\text { westdc.westgis.ac.cn/) }\end{array}$ & $1: 1,000,000$ & $\begin{array}{l}\text { (Soil-Plant-Atmosphere-Water) field and pond hydrology model was used to calculate } \\
\text { some parameters }\end{array}$ \\
\hline Weather & $\begin{array}{l}\text { China Meteorological Administration } \\
\text { (Daily) }\end{array}$ & & 13 Weather stations \\
\hline $\begin{array}{l}\text { Hydrological } \\
\text { observation }\end{array}$ & Hydrologic yearbook (Daily) & & 4 Stations \\
\hline River flow & $\begin{array}{l}\text { Data Center of Chinese Academy of } \\
\text { Science }\end{array}$ & $1: 250,000$ & River network-diversion \\
\hline Glacier & $\begin{array}{l}\text { Regional Database (http:// } \\
\text { westdc.westgis.ac.cn/) }\end{array}$ & $1: 100,000$ & The attribution includes information on width, length and depth \\
\hline
\end{tabular}

$M_{g l a}= \begin{cases}\left(F_{M}+r_{\text {ice } / \text { snow }} I\right) T_{B} & : T_{B}>0{ }^{\circ} \mathrm{C} \\ 0 & : T_{B} \leqslant 0^{\circ} \mathrm{C}\end{cases}$

where $F_{M}$ is a melt factor; $r_{\text {rice/snow }}$ is radiation factor between ice and snow; $I$ is the clear-sky direct radiation. $T_{B}$ is the band-averaged temperature $\left({ }^{\circ} \mathrm{C}\right)$. The site-specific parameters $F_{M}$ and $r_{\text {rice/snow }}$ is further calibrated by direct observations.

$\frac{d h}{d t}=-(1-f) M_{g l a}-S+F$

where $f$ is ratio for melt water refreezing; $M_{g l a}$ is melt rate of glacier in given day $\left(\mathrm{mm} \mathrm{H}_{2} \mathrm{O}\right)$; $\mathrm{S}$ is sublimation rate of glacier in given day $\left(\mathrm{mm} \mathrm{H}_{2} \mathrm{O}\right) ; \mathrm{F}$ is glacier accumulation rate in given day $(\mathrm{mm}$ $\mathrm{H}_{2} \mathrm{O}$ ), and $t$ is the time step in day. Therefore, the depth of water equivalent of glacier mass is expressed as:

$V_{g l a}=\frac{h \times A_{g l a}}{\rho_{\mathrm{i}}}$

where $\rho_{\mathrm{i}}$ is the bulk density of ice, usually, $0.9 \mathrm{~kg} \mathrm{~m}^{-3}$. To capture the seasonal and gradual pattern of the accumulation, we develop an algorithm to account for the accumulation of glacier mass. Turnover of snow to ice is assumed as a ration of water equivalent of snow over ice given as below:

$F=\beta \times S N O_{i}$ where SNO is the water content of snowpack over ice on day $i(\mathrm{~mm}$ $\mathrm{H}_{2} \mathrm{O}$ ), $\beta$ is an accumulation coefficient which is assumed to be changing seasonally and given as follows (Luo et al., 2013):

$\beta=\beta_{0}\left\{1+\sin \left[\frac{2 \pi}{365}(t-81)\right]\right\}$

where $\beta_{0}$ is a basal accumulation coefficient.

\subsection{Snowmelt routing algorithm}

Upon the occurrence, snowfall is deposited on the ground in the form of snow cover or snowpack. The SWAT model sets a threshold temperature to determine snow accumulation. If the daily mean air temperature is below this threshold, the precipitation within an HRU will be modeled as snow, and otherwise as rainfall. When snowfall occurs, its water equivalent will be added to the snowpack. In the model, the snowpack is intensified as snowfall proceeds, and is weakened as the snow melts. The mass balance of snowpack is computed as follows (Neitsch et al., 2005):

$S N_{i}=S N O_{i-1}+R_{d a y}-E_{\text {sub }}-S N O_{m l t}-S N O_{g l a}$

where $\mathrm{SNO}_{i}$ is the water content of snowpack on day $i\left(\mathrm{~mm} \mathrm{H}_{2} \mathrm{O}\right)$, $S N_{i-1}$ is that on day $i-1\left(\mathrm{~mm} \mathrm{H}_{2} \mathrm{O}\right), R_{\text {day }}$ is the precipitation amount on a given day (added only if the average daily temperature 
$T_{a v e}$ is $\left.<T_{s-r}\right)\left(\mathrm{mm} \mathrm{H}_{2} \mathrm{O}\right), E_{\text {sub }}$ is the amount of sublimation on a given day $\left(\mathrm{mm} \mathrm{H}_{2} \mathrm{O}\right) . S N O_{m l t}$ is the amount of snowmelt on a given day $\left(\mathrm{mm} \mathrm{H}_{2} \mathrm{O}\right.$ ) and $\mathrm{SNO}_{\text {gla }}$ is the amount of glacier converted from snow on a given day $\left(\mathrm{mm} \mathrm{H}_{2} \mathrm{O}\right)$. Further information on the equations used in SWAT to calculate snow sublimation has been described in the SWAT Theoretical Documentation (Neitsch et al., 2005).

\subsection{Snowpack temperature}

The distribution of snowpack is not uniform across a given area due to topographical variation and many other factors. Some areas of the watershed may be covered by thick snow, while other areas are free of snow. When conducting the simulation of streamflow, such regions need to be given specific handling so as to accurately calculate the snowmelt. In this study, a depletion curve expresses the seasonal growth and decay of snowpack as a function of the amount of present snow in the basin. This curve is based on natural logarithm (Neitsch et al., 2005). The snowpack temperature on the current day is calculated as follows:

$T_{\text {snow }}(i)=T_{\text {snow }}(i-1) \times\left(1-l_{\text {sno }}\right)+\overline{\operatorname{Ta} v} \times l_{\text {sno }}$

where $T_{\text {snow }}(i)$ is the snowpack temperature on a given day $\left({ }^{\circ} \mathrm{C}\right)$, $T_{\text {snow }}(i-1)$ is that on the previous day $\left({ }^{\circ} \mathrm{C}\right) . l_{\text {sno }}$ is the snow temperature lag factor, and $\overline{T a v}$ is the mean air temperature on the current day $\left({ }^{\circ} \mathrm{C}\right)$. As $l_{s n o}$ approaches 1.0 , the mean air temperature on the current day will increasingly influence the snowpack temperature when the snowpack temperature from the previous day exerts increasingly less influence.

\subsection{Snowmelt process}

Temperature index with elevation band approach is used to study the snowmelt process (Hock, 2003). Snowmelt is determined by the temperatures of atmosphere and snowpack, the melting rate, and the area coverage of snow. The SWAT model regards melted snow as rainfall in the computation of runoff and percolation. Rainfall energy from the fraction of snowmelt is set to be 0 when computing snowmelt, which is estimated under the assumption of uniformly melted snow for $24 \mathrm{~h}$ in a day.

Elevation is one major variable related to particular meteorological parameters, such as temperature and snow amount. SWAT allows to split a watershed into a maximum of ten elevation bands, and then to simulate snow cover or snowmelt at each elevation band (Fontaine et al., 2002). The temperature and precipitation at each band were adjusted accordingly:

$T_{B}=T+\left(Z_{B}-Z\right) \times d T / d Z$
$P_{B}=P+\left(Z_{B}-Z\right) \times d P / d Z$

where $T_{B}$ is the band-averaged temperature $\left({ }^{\circ} \mathrm{C}\right) ; T, Z$ and $P$ are the temperature $\left({ }^{\circ} \mathrm{C}\right)$, elevation $(\mathrm{m})$, and precipitation $(\mathrm{mm})$ respectively, which are measured at the weather stations; $Z_{B}$ is the midpoint of band elevation $(\mathrm{m}) ; d T / d Z$ is the temperature lapse rate $\left({ }^{\circ} \mathrm{C} / \mathrm{m}\right) ; P_{B}$ is the band-averaged precipitation $(\mathrm{mm})$, and $d P / d Z$ is the precipitation lapse rate $(\mathrm{mm} / \mathrm{m})$. Ten elevation bands were set up for the snow-glacier-dominated watershed with vertically equal distance from the mean elevation of the centroid of the subwatershed. $d P / d Z$ and $d T / d Z$ were set to be $0.5 \mathrm{~mm} / \mathrm{km}$ and -0.5 $\left({ }^{\circ} \mathrm{C} / \mathrm{km}\right)$ following local lapse rate calculation. Therefore, the snowpack temperature $\left(T_{\text {snow }}\right)$ and mean daily temperatures were used along with a melt coefficient to calculate the potential volume of melt water. We coupled the glacier melting algorithm to snowmelt process as:

$M=\alpha\left(\left(T_{S N O W}+T_{B}\right) / 2-T_{m}\right)+M_{g l a}$ where $T_{m}$ is the snowmelt base temperature, which is the mean air temperature at which snowmelt occurred. The appropriate melt coefficient approximately ranged between 2 and $6 \mathrm{~mm} / \mathrm{deg}$. The snowmelt coefficient was calculated as:

$$
\begin{aligned}
\alpha= & \left(\alpha_{\max }+\alpha_{\min }\right) / 2+\sin ([(\text { day of year }) \pi / 366])\left(\alpha_{\max }\right. \\
& \left.-\alpha_{\min }\right) / 2
\end{aligned}
$$

where $\alpha_{\max }$ is the maximum snowmelt rate during a year. $\alpha_{\min }$ is the minimum snowmelt rate during a year.

\subsection{Model performance evaluation}

We followed a standard hydrological model performance criterion and used $E_{n s}$ and $R^{2}$ as model evaluation indices in this study. Model performance was high when $E_{n s}>0.5$ and $R^{2}>0.8$. Here, $E_{n s}$ is the relationship strength between observed value $Q_{o, i}$ and simulated value $Q_{m, i}$ at time $t$. $E_{n s}$ lies between $-\infty$ to +1 , which indicates that the model performance is higher when the $E_{n s}$ is closer to +1 . The square of Pearson's product moment correlation, $R^{2}$, presents the proportions of total variance of measured data that can be explained by simulated data, which indicates that the model performance is higher when $R^{2}$ is closer to 1 .

$$
\begin{aligned}
& E_{n s}=1-\frac{\sum_{i=1}^{n}\left(Q_{o, i}-Q_{m, i}\right)^{2}}{\sum_{i=1}^{n}\left(Q_{o, i}-\bar{Q}_{0}\right)^{2}} \\
& R^{2}=\frac{\left[\sum_{i=1}^{n}\left(Q_{o, i}-\bar{Q}_{0}\right)\left(Q_{m, i}-\bar{Q}_{m}\right)\right]^{2}}{\sum_{i=1}^{n}\left(Q_{o, i}-\bar{Q}_{0}\right)^{2} \sum_{i=1}^{n}\left(Q_{m, i}-\bar{Q}_{m}\right)^{2}}
\end{aligned}
$$

$E_{n s}$ is the Nash-Sutcliffe coefficient, $Q_{o, i}$ is the observed runoff in $i$ years, $Q_{m, i}$ is the simulated runoff in $i$ years, and $n$ is the length of the time series. $E_{n s}$ and $R^{2}$ closer to 1 indicate that the model predicts more accurately.

\section{Results}

\subsection{Calibration and validation}

We calibrated and validated the SWAT model with the daily observed data in 2009 and 2010 correspondingly from Yingluoxia Hydrological Station, which is an outlet of the upstream area. The coefficients in Eqs. (12) and (13) were determined by eligible evaluation of calibration and validation. The $R^{2}$ of calibration and validation reached 0.87 and 0.89 respectively. Modeling performance test ( $E_{n s}$ values equals to 0.88 and 0.87 respectively) presents "very good" for both of the model calibration and validation (Fig. 2). Moreover, by comparing the simulation results and observed records from Yingluoxia Hydrological Station, we cannot reject the significance of the parameters of the SWAT model, and consequently the model is shown to be suited to simulate the water balance in the upstream Heihe River Basin. The intervals of the most sensitive parameters were identified, and the most appropriate values are eventually shown in Table 2 . The temperature lapse rate (TLAPS) is the most sensitive parameter since it is directly related to the melting process of snow and glacier. Snow melting occurs mostly from March to June in a subwatershed. The snow melting factor on June 21th was parameterized to be SMFMX, which is the maximum melt rate; any increase of SMFMX drives rapid snow melting. The snow temperature lag factor TIMP is also linked with SMFMX because it is based on the previous situation. Along with TIMP surface water lag time, SURLAG plays an important role in the model performance as a melted snow routing process is related to the geology of the watershed, where the melted water mainly flows to the surface 

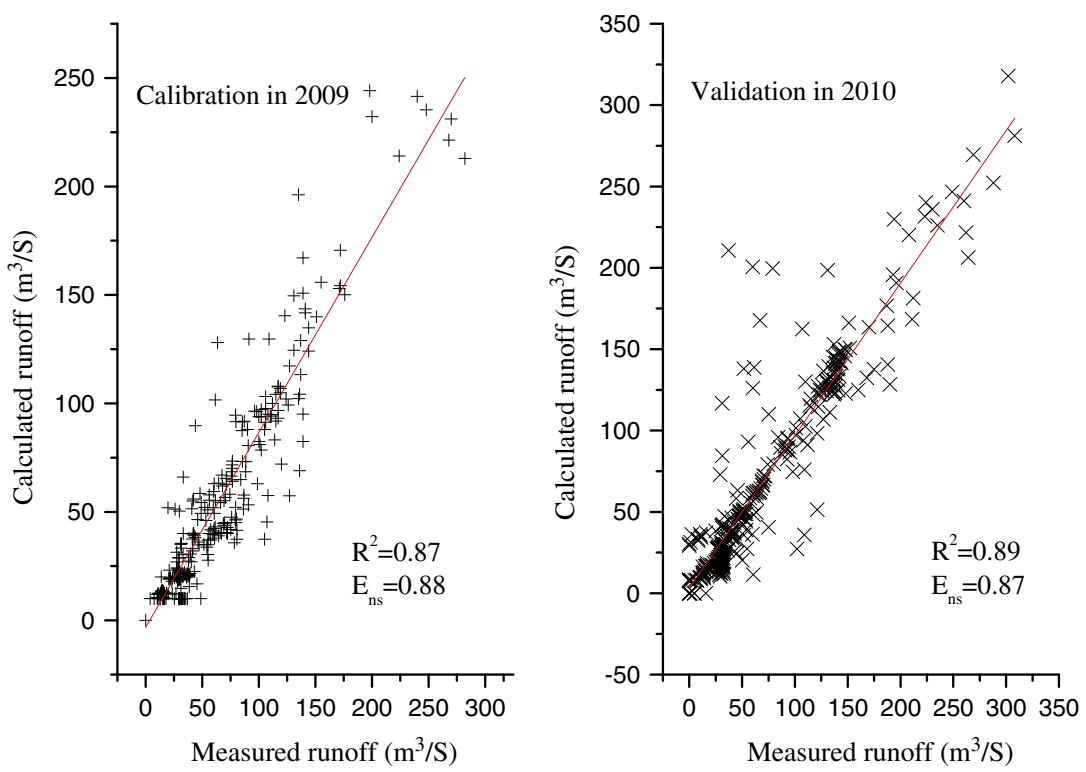

Fig. 2. The calibration and validation of the SWAT model coupled a glacier melting algorithm.

Table 2

List of calibrated parameters and their optimized value.

\begin{tabular}{|c|c|c|c|}
\hline Parameter & Description & Range & Optimized value \\
\hline TLAPS & Temperature lapse rate $\left({ }^{\circ} \mathrm{C} / \mathrm{km}\right)$ & $0,-10$ & -3.8 \\
\hline PLAPS & Precipitation lapse rate $\left(\mathrm{mm} \mathrm{H}_{2} \mathrm{O} / \mathrm{km}\right)$ & 0,100 & 5.8 \\
\hline SFTMP & Snowfall temperature $\left({ }^{\circ} \mathrm{C}\right)$ & $-2,+2$ & 0.9 \\
\hline SMTMP & Snow melt base temperature $\left({ }^{\circ} \mathrm{C}\right)$ & $-5,+5$ & 2.1 \\
\hline SNOEB & Initial snow water content in elevation band ( $\mathrm{mm})$ & 50,230 & 100 \\
\hline TIMP & Snowpack temperature lag factor & $0.38-0.62$ & 0.49 \\
\hline SMFMN & Melt factor for snow on December $21\left(\mathrm{~mm} \mathrm{H}_{2} \mathrm{O} /{ }^{\circ} \mathrm{C}\right.$-day) & $3.05-3.51$ & 3.25 \\
\hline SMFMX & Melt factor for snow on June $21\left(\mathrm{~mm} \mathrm{H}_{2} \mathrm{O} /{ }^{\circ} \mathrm{C}\right.$-day) & $5.85-6.27$ & 6.02 \\
\hline SURLAG & Surface runoff lag time (days) & $4.18-5.19$ & 4.68 \\
\hline$\beta_{0}$ & Basal turnover rate of snow to ice & $0.001-0.006$ & 0.004 \\
\hline
\end{tabular}

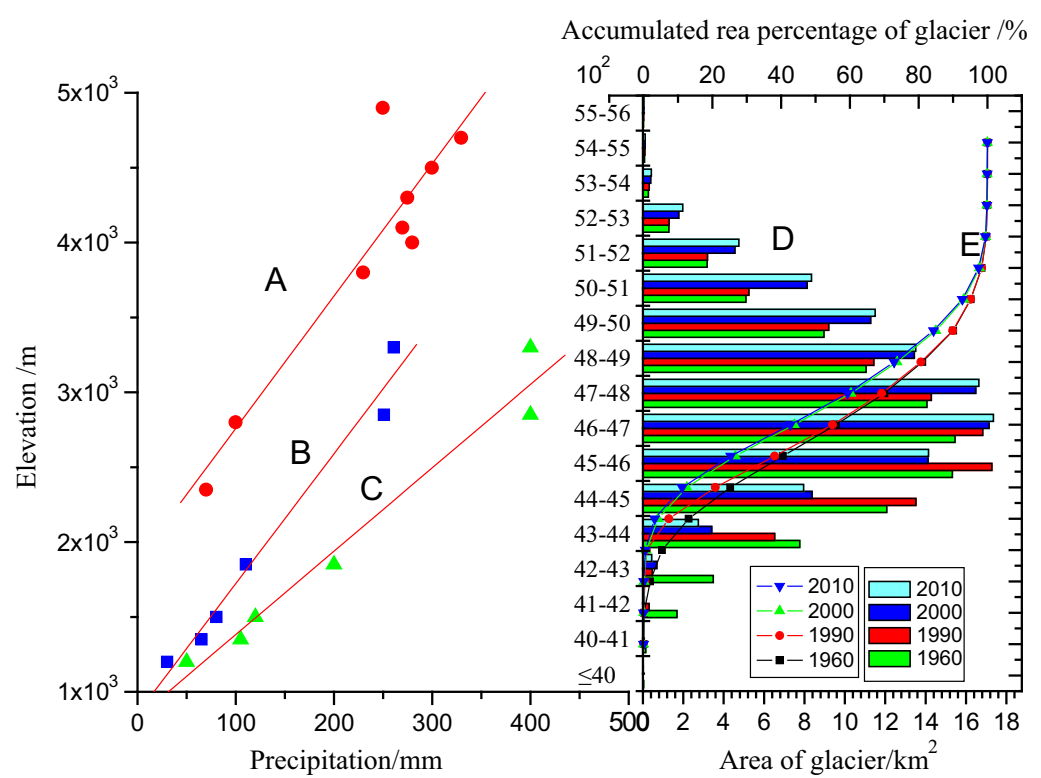

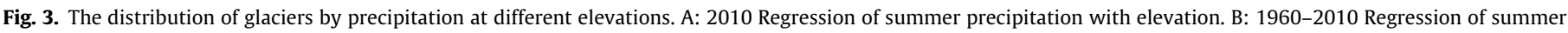

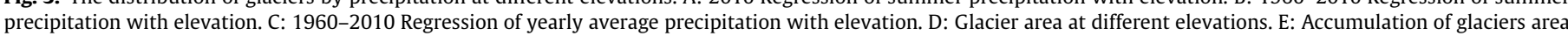
at different elevations. 
Table 3

Simualted relevant changes on the runoff depth with regards to climate changes $(\mathrm{mm})$.

\begin{tabular}{|c|c|c|c|c|c|c|c|}
\hline \multirow[t]{2}{*}{ Precipitation (\%) } & \multicolumn{7}{|c|}{ Temperature change $\left({ }^{\circ} \mathrm{C}\right)$} \\
\hline & 3.0 & 2.5 & 2.0 & 1.5 & 1.0 & 0.5 & 0.0 \\
\hline-10 & -13.56 & -12.94 & -12.33 & -12.21 & -11.87 & -11.45 & -11.02 \\
\hline-5 & -7.62 & -7.37 & -7.21 & -6.99 & -6.62 & -6.13 & -5.51 \\
\hline 0 & -2.32 & -2.01 & -1.79 & -1.48 & -1.12 & -0.53 & 0 \\
\hline 5 & 3.10 & 3.34 & 3.63 & 4.01 & 4.42 & 4.94 & 5.52 \\
\hline 10 & 8.98 & 9.32 & 9.89 & 10.72 & 11.08 & 11.64 & 12.30 \\
\hline
\end{tabular}
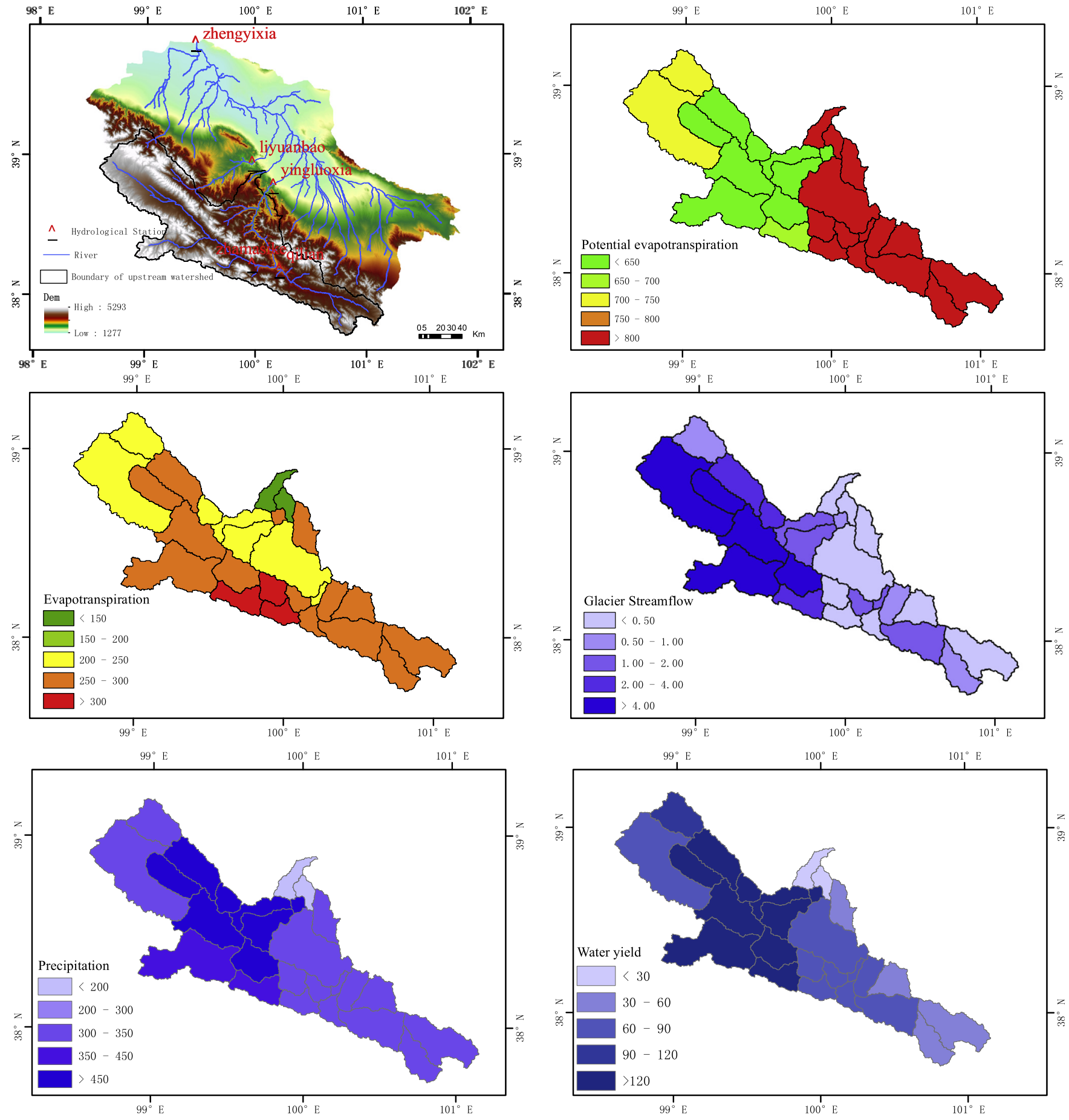

Fig. 4. Distribution of water balance component in the upstream Heihe River Basin in 2010. 
runoff covering the impervious rock formations. SMTMP is sensitive since it indicates the starting and ending of melting and considers the availability of snow melting on a specific day, and the model-simulated streamflow, especially the peak values, is significantly influenced by the variation of SMTMP. Both calibration of the model the validation of the simulation results show that the model performed well in simulating the runoff variation due to glacier melting and climate change in upstream Heihe River Basin.

\subsection{Changes of glaciers}

Changes precipitation and temperature were both seasonally different in alpine during 1960-2010. Precipitation increased in summer and winter and decreased in spring and autumn, and the total annual precipitation increased. Temperature increased in autumn and winter, especially in winter. Temperature decreased slightly in spring and was relatively stable in summer. The annual average temperature increased slowly. The precipitation increased at an annual speed of $1.2 \%$, and increased by $14.84 \mathrm{~mm}$ in summer time per decade, but at a much lower rate in winter time. With seasonal variations of precipitation and temperature in Qilian Mountains in the past 50 years, the two crucial variables both increased on the whole.

Glacier changes are inevitable outcomes of climate changes because they are highly related to temperature and precipitation, both of which are crucially important and determine the annual glacier accumulation, especially in winter time. The observation data of weather stations in the study area show that the precipitation increases with elevation when the elevation is lower than $4700 \mathrm{~m}$. For instance, the annual precipitation increases by $16.9 \mathrm{~mm} / 100 \mathrm{~m}$ and the summer precipitation increase by $10.9 \mathrm{~mm} / 100 \mathrm{~m}$ when the elevation increases (Fig. 3). The precipitation decreases when the elevation exceeds the threshold of $4700 \mathrm{~m}$, and therefore the increase of precipitation should have contributed to the glacier accumulation.

However, the increasing temperature is lead to more rainfall rather than snowfall, which makes glaciers shrinking, increases the liquid ablation, and finally breaks the water balance. The situation is worsening in the winter because glacier accumulation fails to compensate the summer time loss according to our observed records. Therefore, glacier melting in the study area is accelerating.

The history of glacier changes shows that the threshold elevation of glacier change is up to $4700 \mathrm{~m}$, and melting mainly occurs below this threshold since about $6 \%$ of glaciers melted below the threshold and approximate $0.5 \%$ of glaciers accumulated above the threshold. The results show about $3.25 \mathrm{~km}^{3}$ glacial meltwater has contributed to streamflow during 1960-2010.

\subsection{The effect of glacier on streamflow}

Mountainous watersheds possess various geographical characteristics, including mountain glaciers, accumulative snows and frozen soils, which are particularly sensitive to the climate changes. Models about the streamflow's response to climate change in Heihe River Basin revealed that precipitation is the most important factor influencing streamflow. We compared the values simulated with SWAT model and the SWAT model coupled with the glacier melting algorithm, and found that the glacier made about $8.9 \%$ contribution to streamflow in 2010. Especially, streamflow increased at the highest rate of $0.27 \times 10^{8} \mathrm{~m}^{3}$ in spring, which was equivalent to $0.96 \%$ of total streamflow per year. The remarkable increase of streamflow in spring was probably associated with the increasing glacier melting (Fig. 5). Generally, the streamflow increased with precipitation rise and decreased with temperature rise. However, with the stable precipitation in this region, the streamflow will increase by $1.6 \%$ due to the snow melting and glacier melting at the increase of $1.0^{\circ} \mathrm{C}$, and it will decrease by about the same percentage at the decrease of $1.0^{\circ} \mathrm{C}$. When we ignored the impacts of glacier melting on streamflow, we found the runoff depth increased by $12.3 \mathrm{~mm}$ if the temperature was stable and the precipitation increased by $10 \%$, and the runoff depth decreased by $2.32 \mathrm{~mm}$ if the temperature increased by $3{ }^{\circ} \mathrm{C}$ and the precipitation was unchanged (Table 3 ). Therefore, the rising temperature in spring and summer positively contributed to streamflow due to the increase of snowmelt, glacier ablation and annual precipitation. As the temperature and precipitation gradually increase, the streamflow in Heihe mountain area is increasing marginally after a counterbalance of evapotranspiration and infiltration loss. The model-simulated runoff better matches with the observed runoff. However, an initial increase in glacier runoff cannot be sustained because glacier recession will lead to sufficient decrease of glacier area and eventually to decrease in melt-water volumes in the long term.

\subsection{Water balance component}

The SWAT model shows that the spatial distribution of water balance includes rainfall, glaciers melting, and streamflow from sub-watersheds. The SWAT-simulated water yield consists of three components: surface runoff, lateral flow, and shallow groundwater runoff. Among them, lateral flow contributes most to the mountainous runoff, reaching about $54.5 \%$, which exceeds the total contribution of the other two components. Streamflow in the east part of Heihe River Basin was more intensive than that in the west part, and more glaciers are distributed in the east part. Thus, the assumption that the glacier melting changes the streamflow cannot be rejected in this study area.

The water balance results in 2010 are presented in Fig. 4. The results suggest that the precipitation in sub-watersheds of the upstream area ranged from $240 \mathrm{~mm}$ to $760 \mathrm{~mm}$, while the potential evapotranspiration was about two times of the precipitation, and it is higher in the east part (with more forest cover) than in the west part (with higher surface albedo of glaciers). However, the actual evapotranspiration in the west part is slightly lower than the precipitation, within $150-300\left(\mathrm{~mm} \mathrm{H}_{2} \mathrm{O}\right)$. In addition, the simulation results of glacier melting show that the precipitation was within $200-500\left(\mathrm{~mm} \mathrm{H}_{2} \mathrm{O}\right)$ in a spatial pattern of "higher in the west and lower in the east". Water yield is about 30-120 $\left(\mathrm{mm} \mathrm{H}_{2} \mathrm{O}\right)$ after the deduction of evapotranspiration, soil

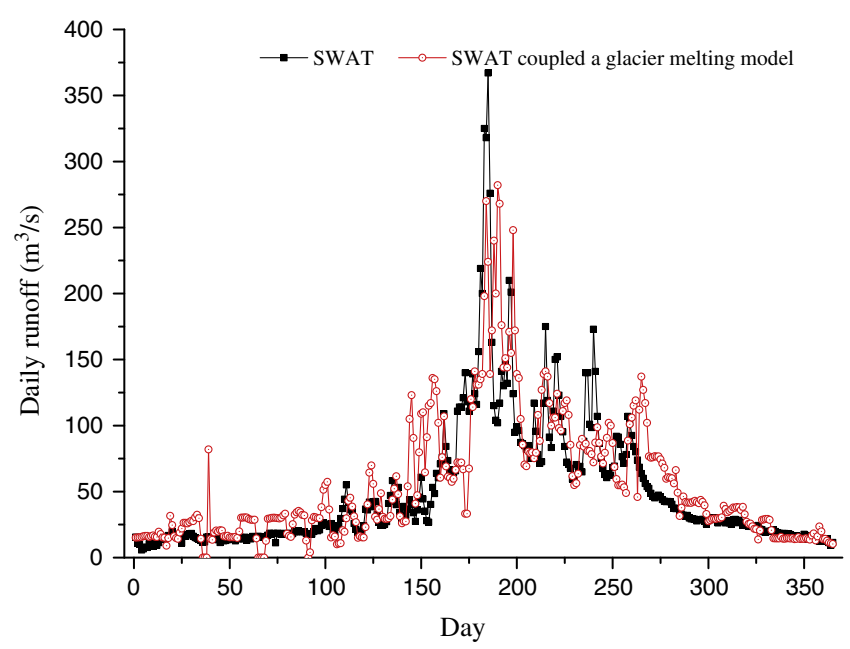

Fig. 5. Comparison of the simulated daily runoff between SWAT and SWAT coupled a glacier melting algorithm in 2010 . 
infiltration and tributary streamflow, and the increase of streamflow within $0.5-4\left(\mathrm{~mm} \mathrm{H}_{2} \mathrm{O}\right)$ is attributed to glacier melting.

This study is constrained with the availability of spatial-explicit high resolution meteorology, topography, and vegetation data, which leads to some statistical bias in the simulation of streamflow in mountainous watersheds. Meanwhile, the glacier melting/snowmelt accumulations of ice/snowpack are superimposed and weak in verification given that lack of the supportive field data. This leave rooms for the further study on the energy balance process of glacier melting by including topographic factors and energy balance. In spite of these limitations, the enhanced SWAT model presented here is shown to be effective in simulating the glacier melting and could be extended to do simulation in other glacierfed watersheds.

\section{Conclusions}

In this study, we present an approach to investigate the contribution of glacier melting and climate change to streamflow by coupling the SWAT model with a glacier melting algorithm. We examine the performance of the improved SWAT model in the upstream Heihe River Basin where topography is complex and the runoff is influenced by snowfall, glacier and climate change. This is the first attempt for predicting future streamflow in the upstream Heihe River Basin. The approach is proved to be effective in simulating glacier melting to describe streamflow changes influenced by climate changes. Technically, calibration is performed using the automatic SWAT-CUP tool. The simulated streamflow better matches with our observed records. The analysis of water balance shows that the glacier melting influences the marginal changes of streamflow, infiltration and evapotranspiration. The model performance is statistically improved by using the elevation band approach, and thus this approach is highly recommended to be applied in those similar mountainous watersheds.

The simulation results indicate that the glacier melting made about $8.9 \%$ contribution to streamflow in 2010. However, such increasing trend of glacier runoff would not sustain since the glacier recession will sufficiently decrease glacier area and thus reduce the melt-water volume in the long run. Our study reveals that alpine glacier of the upstream area is significantly unbalanced in the regional water resource under the current climatic condition, and the glacier would disappear in upstream Heihe River Basin over the next 40 years, as further might make the Heihe River Basin face severer water scarcity in the future. The average snowline will rise by $100 \mathrm{~m}$ at each degree of warming, and the glaciers will also retreat. The results also indicate that the streamflow increased with precipitation rise, and decreased with temperature rise, without considering the contribution of glacier. The elevation around $4700 \mathrm{~m}$ is the threshold of the glacier change, below which, there will be likely less glacier. Meanwhile, the $4700 \mathrm{~m}$ elevation is also the tipping point of precipitation change.

\section{Conflicts of Interest}

The authors declare no conflict of interest.

\section{Acknowledgments}

This research was financially supported by the major research plan of the National Natural Science Foundation of China (Grant No. 91325302), the National Natural Science Funds of China for Distinguished Young Scholar (Grant No. 71225005), and National Key Programme for Developing Basic Science in China (Grant No. 2010CB950900). We would like to thank anonymous referees whose valuable suggestions led to an improved manuscript.

\section{References}

Akhtar, M., Ahmad, N., Booij, M.J., 2008. The impact of climate change on the water resources of Hindukush-Karakorum-Himalaya region under different glacier coverage scenarios. J. Hydrol. 355, 148-163.

Akiyama, T., Sakai, A., Yamazaki, Y., Wang, G., Fujita, K., Nakawo, M., Kubota, J., Konagaya, Y., 2007. Surfacewater-Groundwater Interaction in the Heihe River Basin, Northwestern China.

Arnold, J.G., Srinivasan, R., Muttiah, R.S., Allen, P.M., 1999. Continental scale simulation of the hydrologic balance1. J. Am. Water Resour. Assoc. 35, 10371051.

Barnett, T.P., Adam, J.C., Lettenmaier, D.P., 2005. Potential impacts of a warming climate on water availability in snow-dominated regions. Nature 438, $303-$ 309.

Beniston, M., 2012. Impacts of climatic change on water and associated economic activities in the Swiss Alps. J. Hydrol. 412, 291-296.

Castillo, C.R., Güneralp, İ., Güneralp, B., 2014. Influence of changes in developed land and precipitation on hydrology of a coastal Texas watershed. Appl. Geogr. 47, $154-167$

Debele, B., Srinivasan, R., Gosain, A., 2010. Comparison of process-based and temperature-index snowmelt modeling in SWAT. Water Resour. Manage 24 1065-1088.

Feng, Q., Cheng, G., Endo, K., 2001. Towards sustainable development of the environmentally degraded River Heihe Basin, China. Hydrol. Sci. J. 46, 647658.

Fontaine, T., Cruickshank, T., Arnold, J., Hotchkiss, R., 2002. Development of a snowfall-snowmelt routine for mountainous terrain for the soil water assessment tool (SWAT). J. Hydrol. 262, 209-223.

Glen, J.W., 1955. The creep of polycrystalline ice. Proc. Roy. Soc. London. Series A. Math. Phys. Sci. 228, 519-538.

Hagg, W., Braun, L.N., Kuhn, M., Nesgaard, T.I., 2007. Modelling of hydrological response to climate change in glacierized Central Asian catchments. J. Hydrol. 332, 40-53.

Hock, R., 2003. Temperature index melt modelling in mountain areas. J. Hydrol. 282, $104-115$.

Howells, M., Hermann, S., Welsch, M., Bazilian, M., Segerström, R., Alfstad, T., Gielen, D., Rogner, H., Fischer, G., van Velthuizen, H., 2013. Integrated analysis of climate change, land-use, energy and water strategies. Nat. Climate Change 3, 621-626.

Huss, M., Bauder, A., Funk, M., Hock, R., 2008a. Determination of the seasonal mass balance of four Alpine glaciers since 1865. J. Geophys. Res.: Earth Surface (2003-2012) 113

Huss, M., Farinotti, D., Bauder, A., Funk, M., 2008b. Modelling runoff from highly glacierized alpine drainage basins in a changing climate. Hydrol. Process. 22, 3888-3902.

Immerzeel, W.W., Kraaijenbrink, P.D.A., Shea, J.M., Shrestha, A.B., Pellicciotti, F., Bierkens, M.F.P., de Jong, S.M., 2014. High-resolution monitoring of Himalayan glacier dynamics using unmanned aerial vehicles. Remote Sens. Environ. 150, 93-103.

Li, Z., Xu, Z., Shao, Q., Yang, J., 2009. Parameter estimation and uncertainty analysis of SWAT model in upper reaches of the Heihe River Basin. Hydrol. Process. 23, 2744-2753.

Liew, M.W., Garbrecht, J., 2003. Hydrologic simulation of the Little Washita river experimental watershed using SWAT. J. Am. Water Resour. Assoc. 39, 413-426.

Liu, C., Kang, E., Liu, S., Chen, J., Liu, Z., 1999. Study on the glacier variation and its runoff responses in the arid region of Northwest China. Sci. China, Ser. D Earth Sci. 42, 64-71.

Luo, Y., Arnold, J., Liu, S., Wang, X., Chen, X., 2013. Inclusion of glacier processes for distributed hydrological modeling at basin scale with application to a watershed in Tianshan Mountains, Northwest China. J. Hydrol. 477, 72-85.

Neitsch, S., Arnold, J., Kiniry, J., Williams, J., King, K., 2005. Soil and Water Assessment Tool: Theoretical Documentation, Version 2005. Texas, USA.

Nie, W., Yuan, Y., Kepner, W., Nash, M.S., Jackson, M., Erickson, C., 2011. Assessing impacts of Landuse and Landcover changes on hydrology for the upper San Pedro watershed. J. Hydrol. 407, 105-114.

Nye, J., 1965. The flow of a glacier in a channel of rectangular, elliptic or parabolic cross-section. J. Glaciol. 5, 661-690.

Pradhanang, S.M., Anandhi, A., Mukundan, R., Zion, M.S., Pierson, D.C. Schneiderman, E.M., Matonse, A., Frei, A., 2011. Application of SWAT model to assess snowpack development and streamflow in the Cannonsville watershed, New York, USA. Hydrol. Processes 25, 3268-3277.

Singh, P., Kumar, N., 1997. Impact assessment of climate change on the hydrological response of a snow and glacier melt runoff dominated Himalayan river. J. Hydrol. 193, 316-350.

Thorsteinsson, T., Jóhannesson, T., Snorrason, Á., 2013. Glaciers and ice caps: vulnerable water resources in a warming climate. Curr. Opin. Environ. Sustainability 5, 590-598.

Varanou, E., Gkouvatsou, E., Baltas, E., Mimikou, M., 2002. Quantity and quality integrated catchment modeling under climate change with use of soil and water assessment tool model. J. Hydrol. Eng. 7, 228-244.

Viviroli, D., Weingartner, R., 2004. The hydrological significance of mountains: from regional to global scale. Hydrol. Earth Syst. Sci. Discuss. 8, 1017-1030.

Wang, X., Melesse, A., 2005. Evaluation of the SWAT model's snowmelt hydrology in a northwestern Minnesota watershed. Trans. ASAE 48, 1359-1376. 
Wang, N., Zhang, S., He, J., Pu, J., Wu, X., Jiang, X., 2009. Tracing the major source are of the mountainous runoff generation of the Heihe River in Northwest China using stable isotope technique. Chin. Sci. Bull. 54, 2751-2757.

Yin, Z., Xiao, H., Zou, S., Zhu, R., Lu, Z., Lan, Y., Shen, Y., 2014. Simulation of hydrological processes of mountainous watersheds in inland river basins: taking the Heihe Mainstream River as an example. J. Arid Land 6, 16-26.

Zang, C., Liu, J., 2013. Trend analysis for the flows of green and blue water in the Heihe River Basin, northwestern China. J. Hydrol. 502, 27-36.
Zang, C., Liu, J., Velde, M., Kraxner, F., 2012. Assessment of spatial and temporal patterns of green and blue water flows under natural conditions in inland river basins in Northwest China. Hydrol. Earth Syst. Sci. 16, 2859-2870.

Zeng, Z., Liu, J., Koeneman, P.H., Zarate, E., Hoekstra, A.Y., 2012. Assessing water footprint at river basin level: a case study for the Heihe River Basin in Northwest China. Hydrol. Earth Syst. Sci. 16 (8), 2771-2781. 